УДК 346.52:346.2

DOI https://doi.org/10.32849/2663-5313/2019.5.16

\title{
Ярослав Петруненко,
}

канд. юрид. наук, доцент,

доцент кафедри господарського права і процесу

Національного університету «Одеська юридична академія»

\section{УДОСКОНАЛЕННЯ ГОСПОДАРСЬКО-ПРАВОВОЇ ВІДПОВІДАЛЬНОСТІ ЗА ПРАВОПОРУШЕННЯ У СФЕРІ ВИКОРИСТАННЯ ДЕРЖАВНИХ КОШТІВ}

Стаття присвячена визначенню шляхів удосконалення правового забезпечення господарськоправової відповідальності за правопорушення у сфері використання державних коштів. Охарактеризовано форми господарсько-правової відповідальності суб'єктів господарювання за правопорушення у сфері використання державних коштів; виявлено основні недоліки законодавчого регулювання господарсько-правової відповідальності. На підставі проведеного аналізу розроблено пропозииї щодо вдосконалення правового регулювання господарсько-правової відповідальності за правопорушення у сфері використання державних коштів.

Ключові слова: господарсько-правовий засіб, господарське законодавство, правове забезпечення, господарсько-правова відповідальність, державні кошти, ефективне використання.

Постановка проблеми. Суб'єкти господарювання за вчинення ними правопорушень у сфері використання державних коштів несуть юридичну відповідальність у формах і порядку, визначених законодавством України. Між тим сучасний стан правового регулювання господарсько-правової відповідальності характеризується недостатньою ефективністю, що на практиці призводить до численних зловживань і порушень з боку суб'єктів господарювання та знижує ефективність використання державних коштів. У зв'язку з цим видається актуальним вивчення питань господарськоправової відповідальності за правопорушення у сфері використання державних коштів і пошук шляхів удосконалення законодавчого забезпечення такого виду юридичної відповідальності з метою підвищення ефективності механізму їі застосування.

У науковій літературі окремі питання вдосконалення правового регулювання відповідальності суб'єктів господарювання досліджені такими вченими, як В.С. Бєлих, О.Г. Боднарчук, Ю.А. Ведєрніков, О.М. Вінник, О.П. Віхров, Є.П. Губін, В.В. Добровольська, Д.О. Жмуліна, Д.В. Задихайло, О.А. Заярний, О.Р. Зельдіна, А.М. Ісаян, Т.А. Лавренюк, В.К. Мамутов, Л.В. Мілімко, В.М. Пашков, Д.А. Петров, О.П. Подцерковний, В.В. Поєдинок, Г.В. Пронська, Д.В. Слинько, Г.В. Смолин, В.А. Устименко, О.Г. Хрімлі, В.В. Чайковська, Т.І. Швидка, Н.М. Шевченко, М.Л. Шинкар, Р.Б. Шишка, В.С. Щербина, О.Х. Юлдашев, І.М. Ямкова та ін. Господарсько-правові засоби забезпечення ефективного використання державних коштів відбито на рівні окремих наукових публікацій [1, с. 85-90], однак спеціальних наукових досліджень щодо розроблення пропозицій з удосконалення правового забезпечення господарсько-правової відповідальності за правопорушення у сфері використання державних коштів недостатньо, що свідчить на користь актуальності представленої наукової статті й зумовлює інтерес автора до цієї проблематики.

|| Метою статті $є$ розроблення пропозицій щодо вдосконалення правового забезпечення господарсько-правової відповідальності за правопорушення у сфері використання державних коштів. Для досягнення поставленої мети видається необхідним виконати такі завдання: 1) охарактеризувати форми господарсько-правової відповідальності суб'єктів господарювання за правопорушення у сфері використання державних коштів; 2) виявити основні недоліки законодавчого регулювання господарсько-правової відповідальності в означеній сфері; 3) розробити пропозиції щодо можливих способів усунення відповідних недоліків.

Виклад основного матеріалу. За вчинення правопорушень у сфері використання державних коштів суб'єкти господарювання несуть юридичну відповідальність в порядку, визначеному законодавством. При цьому варто погодитись з думкою, що, незважаючи на те що за законодавством України склався 
плюралізм органів, які вправі застосовувати санкції до суб'єктів господарювання (в тому числі деякі господарські санкції), це докорінно не відобразилось на чисельності й наслідках порушень прав споживачів та інших осіб у господарських правовідносинах [2, с. 131].

Тож, як видно, виникає потреба в удосконаленні механізму застосування господарської відповідальності, а також у подальшому розвитку її форм. Для розроблення конкретних пропозицій у цій сфері необхідно більш грунтовно дослідити форми господарської відповідальності та деяких інших видів юридичної відповідальності, до якої суб'єкти господарювання й інші учасники господарських правовідносин можуть притягатися у зв'язку 3 порушеннями у сфері забезпечення ефективного використання державних коштів.

Передовсім варто акцентувати увагу на тому, що одним із учасників господарських правовідносин, що виникають у сфері застосування заходів забезпечення ефективного використання державних коштів, є суб'єкт публічно-владних повноважень, який правомочний приймати рішення щодо виділення бюджетних коштів господарюючим суб'єктам на підставі договорів (у тому числі господарсько-правового характеру), державних цільових програм соціально-економічного розвитку та інших актів, визначених законодавством. Ця обставина обов'язково повинна бути врахована в процесі застосування окремих видів господарських санкцій.

Зокрема, у ч. 2 ст. 231 Господарського кодексу (далі - ГК) України [3], яка регламентує розмір штрафних санкцій, зазначено, що, якщо порушено господарське зобов'язання, в якому хоча б одна сторона є суб'єктом господарювання, що належить до державного сектора економіки, або порушення пов'язане 3 виконанням державного контракту, або виконання зобов'язання фінансується за рахунок Державного бюджету України чи за рахунок державного кредиту, штрафні санкції застосовуються, якщо інше не передбачено законом чи договором, у таких розмірах: за порушення умов зобов'язання щодо якості (комплектності) товарів (робіт, послуг) стягується штраф у розмірі двадцяти відсотків вартості неякісних (некомплектних) товарів (робіт, послуг); за порушення строків виконання зобов'язання стягується пеня в розмірі 0,1 відсотка вартості товарів (робіт, послуг), із яких допущено прострочення виконання за кожний день прострочення, а за прострочення понад тридцять днів додатково стягується штраф у розмірі семи відсотків вказаної вартості.

Аналізуючи зміст вищенаведеної норми, В.С. Щербина вказує на те, що їі пряму дію зведено нанівець застереженням «якщо інше не передбачено законом чи договором». $\mathrm{y}$ зв'язку з цим науковець пропонує з абзацу 1 ч. 2 ст. 231 ГК України виключити слова «чи договором» [4, с. 15]. Обгрунтовується ця думка тим, що коли законом визначений певний порядок стягнення або конкретний розмір штрафу, то він не може бути змінений у договірному порядку.

Із цим зауваженням необхідно погодитись, оскільки такий підхід цілком відповідає загальноприйнятій доктрині господарського та договірного права щодо визначення меж свободи договору. Відповідно до цього підходу, сторони можуть самостійно визначати умови договору, крім випадків, прямо визначених законом.

Окрім того, слова «якщо інше не передбачено договором» неповною мірою узгоджуються 3 приписами ч. 1 ст. 231 ГК України [3], де зазначається, що законом щодо окремих видів зобов'язань може бути визначений розмір штрафних санкцій, зміна якого за погодженням сторін не допускається.

Додатковим аргументом на користь такої позиції слугує уточнення, що міститься в ч. 4 ст. 231 ГК України [3], а саме, якщо розмір штрафних санкцій законом не визначено, санкції застосовуються в розмірі, передбаченому договором. При цьому розмір санкцій може бути встановлено договором у відсотковому відношенні до суми невиконаної частини зобов'язання, або в певній, визначеній грошовій сумі, або у відсотковому відношенні до суми зобов'язання незалежно від ступеня його виконання, або в кратному розмірі до вартості товарів (робіт, послуг).

У зв'язку з цим видається доцільним дещо уточнити положення ч. 1 ст. 231 ГК України [3], вказавши, зокрема, що розмір штрафних санкцій може визначатися законом чи договором, однак якщо такий розмір визначений у законі, то в договірному порядку його зміна не допускається.

Стосовно інших форм господарсько-правової відповідальності, зокрема відшкодування збитків та оперативно-господарських санкцій, то щодо їх застосування не встановлено якихось особливих вимог, якщо учасником господарських правовідносин є орган державної влади або суб'єкт господарювання державної форми власності. На цій підставі можна зробити висновок, що останні несуть відповідальність у загальному порядку.

Зокрема, наприклад, відповідно до ст. 38 Закону України «Про публічні закупівлі» [5], за порушення вимог, установлених цим Законом і нормативно-правовими актами, розробленими відповідно до цього Закону, члени тендерного комітету замовника, уповноважена особа (особи), члени органу 
оскарження, службові (посадові) особи Уповноваженого органу, службові (посадові) особи органів, що здійснюють казначейське обслуговування бюджетних коштів (обслуговуючого банку), несуть відповідальність згідно із законами України. За порушення вимог, установлених цим Законом у частині прийнятих рішень, вибору й застосування процедур закупівлі, відповідальність несуть члени тендерного комітету або уповноважена особа (особи) персонально.

Як видно з наведеної норми, конкретні види юридичної відповідальності, до якої можуть притягуватись вищезазначені особи, не уточнюються. Проте господарсько-правова відповідальність цих осіб може виражатися, зокрема, у формі відшкодування шкоди, завданої суб'єкту господарювання незаконним рішенням, дією або бездіяльністю. Подібне рішення адміністративний суд постановляє разом із прийняттям рішення щодо визнання відповідних рішення, дії або бездіяльності незаконними.

У сфері господарських правовідносин стосовно забезпечення ефективного використання державних коштів до осіб, що вчинили правопорушення, можуть застосовуватися також оперативно-господарські санкції. Однією 3 поширених господарських санкцій цієї форми господарсько-правової відповідальності є покладення на суб'єкта господарювання-правопорушника обов'язку повернути незаконно отриману державну допомогу.

Положеннями ст. 14 Закону України «Про державну допомогу суб'єктам господарювання» [6] передбачається, що уповноважений орган приймає рішення про повернення незаконної державної допомоги в разі визнання їі недопустимою для конкуренції. Рішення про повернення такої державної допомоги надсилається надавачеві державної допомоги протягом трьох днів із дня його прийняття. Надавач державної допомоги зобов'язаний ужити необхідних заходів щодо забезпечення повернення незаконної державної допомоги, недопустимої для конкуренції, іiї отримувачем відповідно до рішення Уповноваженого органу та повідомити Уповноваженому органові про виконання його рішення в установлений строк. У разі невиконання рішення про припинення або повернення незаконної державної допомоги, недопустимої для конкуренції, Уповноважений орган звертається до окружного адміністративного суду, територіальна юрисдикція якого поширюється на місто Київ, з позовом про визнання відповідного нормативно-правового чи акта індивідуальної дії, на підставі якого надавалася така державна допомога, незаконним і про припинення та/або повернення незаконної державної допомоги.
Повернення суб'єктом господарювання незаконно одержаної державної допомоги регламентовано Порядком, що затверджений Постановою Кабінету Міністрів України від 4 липня 2017 р. № 468 [7]. Передбачено, що на виконання рішення Уповноваженого органу отримувачі незаконної державної допомоги зобов'язані: 1) повернути незаконну державну допомогу в спосіб, визначений рішенням Уповноваженого органу; 2) учинити дії, передбачені заходами надавача незаконної державної допомоги для забезпечення iï повернення; 3) інформувати надавача незаконної державної допомоги й Уповноважений орган про виконання рішення Уповноваженого органу; 4) надати надавачу й Уповноваженому органу докази виконання рішення з поданням засвідчених у встановленому порядку копій документів, які підтверджують перерахування та/або інший спосіб виконання рішення Уповноваженого органу.

До оперативно-господарських санкцій також можна зарахувати відмову суб'єкту господарювання в участі в процедурі закупівлі та відхилення його тендерної пропозиції з підстав, визначених ч. 1 ст. 17 Закону України «Про публічні закупівлі» [5]. Однак серед таких підстав не зазначено порушення суб'єктом господарювання в попередні роки умов договору про закупівлю. Утім, на нашу думку, було б доцільно доповнити ч. 1 ст. 17 Закону України «Про публічні закупівлі» [5] відповідною підставою.

До форм господарсько-правової відповідальності законодавець зараховує також адміністративно-господарські санкції, які за своєю юридичною природою тяжіють до адміністративної відповідальності, однак мають певні особливості. Зокрема, за змістом ст. 238 ГК України [3], адміністративногосподарські санкції визначаються як заходи організаційно-правового або майнового характеру, спрямовані на припинення правопорушення суб'єкта господарювання та ліквідацію його наслідків. При цьому наголошується, що адміністративно-господарські санкції можуть бути встановлені виключно законами. Варто зауважити, що від санкцій за вчинення адміністративних правопорушень адміністративно-господарські санкції відрізняються головним чином процедурою їх застосування, суб'єктами відповідальності (зокрема суб'єктами адміністративної відповідальності може бути фізична особа, в тому числі суб'єкт підприємницької діяльності, або керівник чи посадова особа підприємства, установи, організації, вина якої доведена в установленому порядку), а також характером заходів, які здійснюються в межах застосування відповідної санкції. 


\section{Висновки}

Підсумовуючи вищевикладене, можемо констатувати, що за результатами дослідження видається можливим сформулювати узагальнені висновки та надати пропозиції. Для вдосконалення законодавства, що регулюе відповідальність суб'єктів господарювання й інших учасників господарських правовідносин, що виникають у сфері забезпечення ефективного використання державних коштів, необхідно внести такі зміни та доповнення до:

1) ГК України [3], зокрема, ч. 1 ст. 231 пропонується викласти в такій редакції: «Розмір шттрафних санкиій може визначатися законом чи договором. Якшо законом шодо окремих видів зобов'язань визначено розмір штрафних санкиій, його зміна в договірному порядку не допускається»;

2) Закону України «Про публічні закупівлі» [5]: ч. 1 ст. 17 доповнити п. 11, який пропонується викласти в такій редакції: «у замовника (уповноваженої особи) або Уповноваженого органу $є$ достовірна інформачія (підтверджена судовим рішенням, яке набрало законної сили, або актом органу державної влади), що суб'єкт господарювання (учасник) протягом останніх трьох років був стороною договору про закупівлю чи державного контракту й допустив суттєве порушення умов такого договору, зокрема, щодо строків поставки товарів (виконання робіт, надання послуг), якості й кількості поставленої продукиіі (робіт, послуг), відповідності поставленої продукції визначеним у тендерній документачії технічним умовам»; ст. 37 змінити, виклавши їі назву в редакції «Недійсність договору про закупівлю та його розірвання» й доповнивши ч. 2 такого змісту: «Договір про закупівлю може бути розірвано на вимогу замовника (уповноваженої особи) або Уповноваженого органу, якщо під час його виконання буде виявлено суттєве порушення його умов учасником-переможием проиедури закупівлі. У такому випадку має бути проведена нова процедура закупівлі».

\section{Список використаних джерел:}

1. Петруненко Я.В. Господарсько-правова природа засобів забезпечення ефективного використання державних коштів. Підприємниитво, господарство і право. 2017. № 3. С. 85-90.

2. Шишка Р.Б. Окремі аспекти господарськоправової відповідальності. Юридичний вісник. 2015. № 1 (34). C. 129-133.

3. Господарський кодекс України від 16 січня 2003 р. / Верховна Рада України. Офіційний вісник України. 2003. № 11. Ст. 462. База даних «Законодавство України». URL: http://zakon.rada.gov.ua/laws/show/436-15.

4. Щербина В.С. Господарсько-правова відповідальність: галузевий підхід, особливості застосування та напрямки подальших наукових досліджень. Вісник Київського начіонального університету ім. Тараса Шевченка. Серія «Юридичні науки». 2013. Вип. 3 (79). С. 10-16.

5. Про публічні закупівлі: Закон України від 25 грудня 2015 р. № 922-VIII / Верховна Рада України. Відомості Верховної Ради України. 2016. № 9. Ст. 89. URL: https://zakon.rada.gov.ua/laws/ show/922-19.

6. Про державну допомогу суб'єктам господарювання: Закон України від 1 липня 2014 р. № 1555-VII / Верховна Рада України. Відомості Верховної Ради України. 2014. № 34. Ст. 1173. База даних «Законодавство України». URL: https:// zakon.rada.gov.ua/laws/show/1555-18

7. Про затвердження Порядку повернення незаконної державної допомоги, недопустимої для конкуренції: Постанова Кабінету Міністрів України від 4 липня 2017 р. № 468 / Кабінет Міністрів України. Офіиійний вісник України. 2017. № 57. Ст.1696. Базаданих «Законодавство України». URL https://zakon.rada.gov.ua/laws/show/468-2017-п.

Статья посвящена определению путей усовершенствования правового обеспечения хозяйственно-правовой ответственности за правонарушения в сфере использования государственных средств. Охарактеризованы формы хозяйственно-правовой ответственности субъектов хозяйствования за правонарушения в сфере использования государственных средств; выявлены основные недостатки законодательного регулирования хозяйственно-правовой ответственности. На основе проведённого анализа разработаны предложения относительно усовершенствования правового регулирования хозяйственноправовой ответственности за правонарушения в сфере использования государственных средств.

Ключевые слова: хозяйственно-правовое средство, хозяйственное законодательство, правовое обеспечение, хозяйственно-правовая ответственность, государственные средства, эффективное использование.

The article is devoted to the definition of ways to improve the legal framework for economic and legal responsibility for offenses in the use of public funds. Characterized forms of economic and legal responsibility of economic entities for offenses in the sphere of using public funds; revealed the main shortcomings of the legislative regulation of economic and legal responsibility. On the basis of the analysis, proposals were made to improve the legal regulation of economic and legal responsibility for offenses in the sphere of the use of public funds.

Key words: economic and legal means, economic legislation, legal support, economic and legal responsibility, public funds, effective use. 